Cornu proceeds (Paragraph V.) to sketch "the most favourable conditions for the introduction of the insect" as follows:- "A phylloxera is removed in the soil, say a pregnant mother, which survives for a period of five days ; it lays an egg before dying ; the egg takes fifteen days to hatch (at the mean temperature of $59 \mathrm{deg}$. Fahr.), and the young insect which is produced five days to die. This makes in all twenty-five days." That is to say, that the maternal phylloxera, when in articulo mortis at the end of her five days' dessication and starvation, is to lay an egg; that this egg, produced under such extraordinary conditions, is to hatch in due course, and, after undergoing total starvation from its birth, is to live out the normal term of five days allotted to the mother (presumably well fed intil she started on the dolorous voyage), and after all this is to land at the Cape and propagate its species in the nearest vineyard at hand! If these are "the most favourable conditions" under which the phylloxera would be introduced, we may surely say with Dr. Cornu in another part of the same report (Paragraph VII. a) that "it would require a concatenation of circumstances which it is difficult to imagine to bring about the misfortune of the insect's introduction." It is as well also to note that the writer expressly states (Paragraph V.) that the egg's hatching is accelerated when the temperature exceeds 59 deg. Fahr., so that in the supposed case, if the starveling progeny ever did see the light on the voyage, it would probably emerge in a tropical temperature long before the normal fifteen days allowed, and so resign its life of total abstinence before reaching the promised land of plenty at the Cape.

Let us now turn to the "winter egg," which, as Dr. Cornu states (Paragraph VI.), "is particularly to be dreaded." This is the rarest condition of the insect, each female of the generation which includes both sexes laying only one egg (Paragraph VI.).

"It is to this egg alone that the introduction of the phylloxera in packing-cases, straw, \&c., could be attributed; this would however require confirmation; in fact I am not aware of any well-authenticated instance of the introduction of the phylloxera resulting from the transmission of the winter egg" (Paragraph VII.).

This admission on the writer's part seems to reduce any apprehension about the winter egg to infinitesimal proportions, especially when it is noted that the "winter egg," as its title implies, is a state limited to cold weather, and "commences to develop at the return of the fine weather" (Paragraph VI.). If a specimen of this rare ceuf d'hiver did by any chance (in the absence of the vine-stems or branches upon which it is laid) start on a voyage for South Africa, we may be very sure that in its passage through the whole extent of both tropics it would very speedily cease to merit its title, and become a miserable phylloxìra d'été, only to share the fate of its luckless relative, produced from the last dying egg of the mere pondeuse. It does not mend matters to find Dr. Cornu stating in italics (Paragraph VII.), "Such introduction is nevertheless possible from a scientific point of view." Impossibility can with accuracy be predicated of but very few propositions; as a rule it is safer to say of most matters apparently incredible that it is next to impossible, and this may very certainly be said in the present case; and when all known facts and conditions place every pro!Jability against a bare possibility, wise men will know how to act.

As long as vines and all parts of vines from abroad are kept out of the Cape, the requirements of the wine industry are fully met. This prohibition was put in force by the late Government, by Proclamation No. 88, of November 30,1876 , and has been in force ever since that date. As latc as the 4th December last, attention was specially directed to this Proclamation, with the intimation that its provisions would be strictly enforced (in Government Notice, No. I28S, of I879) The present superfluous and vexatious restrictions were added by Proclamation No. I4, of January, 1880, and all the facts adduced by Dr. Cornu point to their futility.

\section{SONGS OF THE SCIENCES-I. ZOOLOGY}

WE must regard it as a noteworthy sign that science has begun to percolate so through society generally that it has reached the pages of Punch. Almost every week we find a bit of more or less telling waggery, and last week the first of a series of "Songs of the Sciences" appeared, which we reproduce :-

$\mathrm{Oh}$ ! merry is the Madrepore that sits beside the sea, The cheery little Coralline hath many charms for me; I love the fine Echinoderms of azure, green, and grey, That handled roughly fing their arms impulsively away : Then bring me here the microscope and let me see the cells, Wherein the little Zoophite like garden floweret dwells.

We'll take the fair Anemone from off its rocky seat, Since Rondeletius has said when fried 'tis good to eat ; Dyspeptics from Sea-Cucumbers a lesson well may win, They blithely take their organs out and then put fresh ones in. The Rotifer in whirling round may surely bear the bell, With Oceanic Hydrozoids that Huxley knows so well.

You've heard of the Octopus, 'tis a pleasant thing to know, He has a ganglion makes him blush not red, but white as snow : And why the strange Cercaria, to go a long way back, Wears ever, as some ladies do, a fashionable "sac": And how the Prawn has parasites that on his head make holes, Ask Dr. Cobbold and he'll say they're just like tiny soles.

Then study well zoology, and add unto your store, The tales of Biogenesis and Protoplasmic Iore:

As Paley neatly has observed, when into life they burst, The frog and the philosopher are just the same at first. But what's the origin of life remains a puzzle still, Let Tyndall, Haeckel, Bastian go wrangle as they will.

\section{THE AUGUST AURORAS}

$A S$ I had the pleasure of witnessing to great advantage $\mathrm{A}$ at Christiania the superb aurora of August i2 last, as well as that of the I3th, it is possible that some account of these displays as seen in Norway may be useful for comparison with accounts of their appearance in England.

My attention was first drawn to the aurora on going into the open air at II p.m. At I0.30 p.m. a friend had remarked that the night seemed unusually dark, and that the stars were shining brightly. When first seen by me the aurora consisted of a wide arch of diffused light, the centre of which was about $30^{\circ}$ in height. A few broad streamers were then beginning to appear. I walked as quickly as possible to a hill whence a good view could be obtained, but I had hardly got there before the aurora had already reached, about I r.Io p.m., its maximum splendour. Broad streamers had by this time covered almost the whole of the northern half of the heavens, converging to a point considerably south of the zenith, forming a grand corona. The arch was still highly luminous, and from its upper margin coruscations or waves of white light shot up every two or three seconds towards the zenith. At this time also there suddenly appeared to the east of magnetic north a splendid sheaf of rays proceeding from the horizon altogether beyond the auroral arch, and apparently in complete independence of it. These rays, through bright, attained an elevation of only some $35^{\circ}$, and belonged apparently to a distinct auroral discharge. At II.15 the arch had already begun to fade, but a mass of rays shone out brightly near its eastern termination. Throughout the display I was struck by the tendency to the formation of compact bodies of streamers which seemed to flank each end of the arch. As the arch faded the pulsations of 
light increased in frequency and brilliancy, and at $\mathrm{I} I .25$ they might be described as broad flashes overspreading a large part of the northern half of the sky, always travelling upwards, and sometimes passing the zenith. The main body of streamers had by this time mostly faded, after going through an extraordinary series of charges which I found it quite impossible to record. Every minute or two new rays would strike up to the zenith, or sometimes beyond, and every now and then a portion of an older ray would suddenly shine out with a kind of phosphoric light.

The display now rapidly faded, and though at II.35 and again about II.45 there were minor reappearances of rays, the aurora seemed to be near its end, and I returned home.

The brightness of the phenomenon was somewhat delusive; for when a superb corona of rays covered the northern sky, I could only just read my watch by its light, and could not read what I endeavoured to write down on paper. The light was either white or of a greenish yellow tinge. There was no trace of the redness or other colours seen on other occasions.

By very good fortune I was able to watch the aurora of the next night (August 13) under the most favourable possible circumstances, namely, while steaming down the Christiania Fyord, in the steamship Angelo, during a beautiful calm evening. The aurora began at Io.20 p.m. with a very faint uniform arch, or rather line of white light, appearing $8^{\circ}$ or $10^{\circ}$ above the horizon, with difficulty distinguished from the twilight. This soon faded away entirely; but at 10.35 reappeared as a very distinct luminous arch, separated by a dark space from the twilight. Some slight signs of rays now also appeared.

At 10.45 the arch seemed to be rising somewhat, without ever attaining a height of more than about $15^{\circ}$. The lower edge became indented by ray-like notches. There was a tendency to the formation of streamers at the flanks. At 10.50 a fine single ray shot up from the horizon right through the arch, at $10^{\circ}$ to west of true north. Streamers also began to appear above the arch, and especially at its eastern end ; but the streamers were in no way comparable to those of the previous night. The arch now began to lose its previous regular form, and to go through a remarkable series of gradual changes and contortions, which it is impossible to describe. By degrees the eastern end became incurved in the manner of a folded curtain (like the pictures of auroras in the Polar regions which we see in books), and a few fragments of rays tended to form an inferior arch.

For more than an hour the light of this aurora was steady; but about II.30 p.m. pulsations first began to appear faintly, soon increasing in frequency and width. As the pulsations grew the arch almost insensibly disappeared, but patches of light and fragments of rays occupied the sky above where the arch had been, and were every instant lighted up, as it were, by the passing coruscations. These flashes of light became more and more frequent, following each other every second, or even several times in a second, so as to produce at last a kind of rustling or dancing appearance. They were most intense upon the rays and patches, but were not confined to them. At 12.30 the display was failing, the waves being less frequent. At I a.m. there remained only a few irregular patches of faint, steady light, with occasional flashing waves. The light was again white, or greenish yellow. On neither occasion did the aurora secm to have the slightest relation to the ordinary vaporous clouds of the atmosphere, nor did the dark space beneath the arch seem to be more than might be explained as the effect of contrast.

Mr. Thomas Bennett, who is well known to all Norwegian travellers, and has resided many years in Christiania, informed me that the aurora of the I2th was probably the finest he had ever secn among the many grand displays which occur in Norway. Though I have witnessed several fine auroras, including some of those seen in the United States in August and September, I859, and two fine displays of the Aurora Australis (September I4 and I6, I854), I cannot call to mind that I ever saw coruscations or waves of electric light at all approaching those seen at Christiania on this occasion. The books say comparatively little about these coruscations, nor do the letters in NATURE, vol. xxii. p. 36r, mention them as seen in England. Yet they probably represent the most important part of the phenomenon, the active discharge of electric energy.

I neither saw nor heard anything in Norway of an aurora on the night of August II. About the dates I give there can be no possible mistake, because the steamboat from Christiania to Hull departed as usual on Friday evening (August 13 ). The times mentioned are the local times by the public clock at the Christiania University Buildings. W. STANLEY JEVONS

P.S.-The above account was mostly written a few days after my return to London. according to notes taken at the time. I print it now for what it may be worth. After thinking the matter over for three months, and comparing the auroral coruscations above described with the exquisite discoveries of Mr. Crookes, taking into account also some remarks in the article on auroras in the new edition of the "Encyclopædia Britannica," I venture to make the suggestion that these coruscations arise from highly tenuous matter (in what $\mathrm{Mr}$. Crookes calls the radiant state) projected through the higher parts of the atmosphere. It is not possible by words to give an impression of such a phenomenon in the least degree approaching to that naturally acquired by watching it under favourable circumstances for several hours. My belief is, that during the auroras described, puffs, as it were, of radiant matter were discharged at a great elevation above the earth's surface, and the luminosity of these puffs perhaps arises from conflicts between the projected molecules and those already spread about the almost vacuous space. The arch and most of the streamers probably belong to a lower, though still a very high part of the earth's atmosphere, but certain of the streamers, as well as patches of luminous matter seen on the night of the 13 th, certainly exist in the lofty regions through which the radiant matter is projected. The explanation of the streamers must probably be approached through that of the coruscations, but they are effects of a very different kind.

November 22

\section{THE INFLUENCE OF A TUNING-FORK ON THE GARDEN SPIDER}

HAVING made some observations on the garden spider which are I believe new, I send a short account of them in the hope that they may be of interest to the readers of NATURE.

Last autumn, while watching some spiders spinning their beautiful geometrical webs, it occurred to me to try what effect a tuning-fork would have upon them. On sounding an A fork and lightly touching with it any leaf or other support of the web or any portion of the web itself, I found that the spider, if at the centre of the web, rapidly slews round so as to face the direction of the fork, feeling with its fore feet along which radial thread the vibration travels. Having become satisfied on this point, it next darts along that thread till it reaches either the fork itself or a junction of two or more threads, the right one of which it instantly determines as before. If the fork is not removed when the spider has arrived it scems to have the same charm as any fly: for the spider seizes it, embraces it, and runs about on the legs of the fork as often as it is made to sound, never seeming to learn 